\title{
Realisme dalam \\ Pemikiran Ekologis
}

\section{Mutia Hariati Hussin}

Jurusan IImu Hubungan Internasional, Fakultas IImu Sosial IImu Politik, Universitas Muhammadiyah

Yogyakarta

Ringroad Barat Tamantirto, Kasihan, Bantul 55183

Email:mutiasuryo@yahoo.com

\begin{abstract}
Environmental issues have recently become objects of study among international scholars. At the most theoretical level, a number of scholars criticize the ability of the state-system to respond to environmental dangers but at the same time the state-centric thinking still dominating most environmental activities marked by the international environmental regime formation. The two main school of thought involved in this line of enquiry are realist perspective (or paradigm) and the ecological thinking. This article analyses these two conceptions. It aims to show that although the ecological thought present themselves as radical departure from state-centric thinking, they actually reaffirm the dominant realist perspective about the centrality of the institution of the state especially when thinking about forms of formulation able to address global environmental problems.

Keywords:state system, environment issues, realist perspective, ecology perspective
\end{abstract}

\begin{abstract}
Abstrak
Isu lingkungan baru-baru ini menjadi objek penelitian di kalangan ilmuwan internasional. Sejumlah ilmuwan mengkritisi kemampuan negara-sistem dalam merespon bahaya lingkungan, namun diwaktu yang bersamaan pemikiran negara-sentris masih mendominasi sebagian besar aktivitas lingkungan yang ditandai pembentukan rezim lingkungan internasional. Dua pemikiran utama dalam hal ini adalah perspektif realis (paradigma) dan pemikiran ekologis. Tulisan ini membahas dua konsepsi tersebut. Hal ini bertujuan untuk menunjukkan meski pemikiran ekologis menampilkan diri sebagai radikal dari pemikiran negara-sentris, mereka sebenarnya menegaskan dominan perspektif realis tentang sentralitas institusi negara, khususnya ketika berfikir mengenai bentuk formulasi yang mampu mengatasi masalah lingkungan global.

Kata Kunci:sistem Negara, isu-isu lingkungan, perspektif realis, perspektif ekologi.
\end{abstract}

\section{PENDAHULUAN}

Kepekaan studi hubungan internasional, dalam hal ini yang menyangkut pemikiran realis, terhadap isu-isu ekologis yang diwujudkan dengan penyertaan asumsiasumsi ekologis di satu sisi banyak memperlihatkan kelemahan teori-teori realis yang relative simplistic. Di sisi lain, kesulitan dalam merangkai aksi kolektif yang diakibatkan oleh kompleksitas pelaku dan interaksi politik yang terjadi, justru menjadikan realisme semakin didambakan dalam menggalang aksi bersama untuk menghadapi persoalan ekologis.

Pada tahap awal perkembangannya, para ilmuwan politik dan hubungan internasional (HI) seringkali dihadapkan pada dilemma dalam menentukan apakah harus memusatkan peratiannya pada analisa tentang "kenyataan yang ada (what is)" ataukah pada yang "seharusnya ada (what ought to be)"(Rourke, 1986:28). Kelompok what is yang memusatkan perhatian pada kondisi politik pada saat ini dan masa lalu tersebut kemudian dikategorikan sebagai 1) kelompok realis dan 2) kelompok behavioralis (Mas'oed, 1994:14546).

\section{PEMBAHASAN}

Disiplin ilmu hubungan internasional yang dalam hal ini berkisar pada masalah-masalah keseimbangan struktur kekuasaan politik dan ekonomi pada level internasional juga melibatkan masalah-masalah 
ideologi maupun persepsi yang dimiliki para pemimpin sebagai individu pada level domestik (Viotti dan Kauppi, 1990:1)

Ketiga perspektif pada tabel 1 merujuk pada kategorisasi oleh James N. Rosenau mengenai pendekatan-pendekatan dalam politik internasional yaitu state-centric, multi-centric dan global centric (Viotti dan Kauppi, 1990:11). Dengan adanya factor perspektif atau persepsi itu maka kajian politik dalam hubungan internasional seringkali dipandang lebih dari sekedar fakta objektif sehingga timbul anggapan bahwa ilmu HI adalah sebuah studi yang melibatkan penilaian subyektif yang berdasarkan pada cara seorang aktor memandang dirinya sendiri dan aktor internasional lain (Rourke, 1986:25-26). Menurut Carrol (1988:1), 'perceptions equal reality in the context of politics and diplomacy', sehingga ada pendapat bahwa hal-hal yang dianggap penting oleh studi HI seringkali bukanlah yang sebenarnya terjadi namun merupakan sesuatu yang dianggap memang seharusnya demikian. Ladang kajian HI pada perkembangannya kemudian juga diwarnai oleh munculnya isu-isu baru yang memiliki dimensi dan cirri-ciri yang berbeda dengan persoalan-persoalan konvensional dalam hubungan antar bangsa-bangsa. Dimensi yang berbeda dapat dilihat dari cakupannya yang jauh melintasi dan bahkan seringkali tidak mengenal batas-batas sistem yuridiksi bangsa (Rourke, 1986:1). Masalah lingkungan hidup, atau ekologi, adalah salah satu dari persoalan global yang menjadi perhatian dewasa ini.

Konsisten dengan pengkotakan umat manusia secara politis dalam wilayah-wilayah geografis bangsa (nation-state) yang berdaulat maka secara tradisional masalah ekologi ini ditangani oleh masing-masing pemerintahan sebagai masalah dalam negerinya (Domask, 1998:7). Namun, seiring dengan berlipat gandanya peningkatan populasi, kegiatan produksi serta konsumsi, di seluruh dunia telah terjadi suatu kondisi dimana masalah-masalah lingkungan yang biasanya berskala sempit dan bersifat domestic berubah menjadi berdimensi internasional dan telah menciptakan jalinan kerjasama dalam bentuk rejim internasional. Kenyataan bahwa sebagian di dunia mendukung rejim internasional tertentu dan sementara sebagian lainnya menentang, atau memiliki sikap yang berbeda tentang usaha-usaha pelestarian lingkungan hidupglobal yang diupayakan dalam rejimrejim itulah yang menarik untuk ditulis dalam artikel ini.

\section{REALISME DAN LINGKUNGAN HIDUP}

Udara, air, siklus karbon, lapisan ozon dan binatang-binatang yang bermigrasi memiliki antara lain karakteristik yang tidak terbatas pada satu wilayah tertentu menunjukkann kenyataan bahwa masalah lingkungan hidup bukan semata-mata melibatkan kebijakan domestik tetapi juga akan menyangkut organisasi internasional, kebijakan luar negeri dan praktek-praktek politik transnasional lainnya (Environmental Politics, 1995:44). Salah satu upaya yang telah dilakukan oleh para ilmuwan dalam kerangka politik lingkungan internasional adalah memikirkan kembali beberapa konsepsi dasar dalam kegiatan polititk dunia serta mengusulkan berbagai perubahan, terutama dalam sistem bangsa yang dominant, untuk mengurangi berbagai masalah ekologis di dunia ini. Upaya-upaya yang secara longgar digambarkan antara lain melalui pembentukan rejim internasional pada saat ini mewakili pendekatan yang berkeinginan untuk menyusun kembali struktur kekuasaan pada level global dalam rangka menghadapi ancaman-ancaman kerusakan lingkungan.

Para ilmuwan (HI) mengidentifikasikan adanya ketidakmampuan structural yang inheren dalam sistem negara bangsa moderen dan mengusulkan suatu rekonstruksi terhadap sistem tersebut demi alasanalasan lingkungan hidup. Dua aliran pemikiran utama yang digunakan dalam penelitian ini adalah yang dilandasi perspektif realis dan pemikiran ekologis yang masing-masing memiliki konsepsi yang berbeda mengenai beberapa variabel yang sama. Paradigma yang pertama, yang diwakili perspektif realis, neo-realis sampai dengan structural-realist, meliputi pemikiran yang mengakui pentingnya pembentukan rejim internasional dalam kerangka supra-statisme (diatas negara). Pemikiran pertama ini berargumen bahwa 
Tabel 1. Tiga perspektif dalam HI dan asumsi yang mengikutinya

\begin{tabular}{|c|c|c|c|}
\hline & REALIS & PLURALIS & GLOBALIS \\
\hline Unit analisa & sebagai aktor utama & $\begin{array}{l}\text { dan aktor non - sama } \\
\text { pentingnya }\end{array}$ & $\begin{array}{l}\text { Kelompok, dan masyarakat } \\
\text { serta aktor non menjadi } \\
\text { bagian dari system kapitalis } \\
\text { dunia }\end{array}$ \\
\hline Persepsi aktor & $\begin{array}{l}\text { sebagai aktor adalah } \\
\text { sebuah kesatuan yang } \\
\text { utuh }\end{array}$ & $\begin{array}{l}\text { terdiri dari berbagai } \\
\text { komponen yang sebagian } \\
\text { diantaranya mungkin saja } \\
\text { beroperasi secara } \\
\text { transnasional }\end{array}$ & $\begin{array}{l}\text { HI dipandang dari sudut } \\
\text { perspektif sejarah, terutama } \\
\text { yang berhubungan dengan } \\
\text { perkembangan kapitalisme } \\
\text { dunia }\end{array}$ \\
\hline Dinamika & $\begin{array}{l}\text { merupakan aktor rasional } \\
\text { yang berusaha mencapai } \\
\text { hasil maksimal bagi } \\
\text { kepentingan nasional dan } \\
\text { tujuan nasional yang } \\
\text { tercermin dalam kebijakan } \\
\text { luar negerinya }\end{array}$ & $\begin{array}{l}\text { Pembuatan keputusan luar } \\
\text { negeri dan proses } \\
\text { transnasional melibatkan } \\
\text { konflik, tawar-menawar, } \\
\text { koalisi dan kompromi yang } \\
\text { belum tentu memperoleh } \\
\text { hasil yang maksimal }\end{array}$ & $\begin{array}{l}\text { Memusatkan perhatian } \\
\text { pada pola-pola dominasi } \\
\text { yang ada di dalam dan } \\
\text { diantara kelompok- } \\
\text { kelompok masyarakat }\end{array}$ \\
\hline Isu penting & $\begin{array}{l}\text { 'keamanan' nasional, } \\
\text { dalam arti kekuatan } \\
\text { ekonomi-politik dan } \\
\text { militer, merupakan yang } \\
\text { terpenting }\end{array}$ & $\begin{array}{l}\text { Multi agenda dengan isu } \\
\text { sosial-ekonomi dan } \\
\text { kesejahteraan dianggap } \\
\text { sama penting atau bahkan } \\
\text { lebih penting dari isu } \\
\text { keamanan }\end{array}$ & $\begin{array}{l}\text { Faktor ekonomi merupakan } \\
\text { yang terpenting }\end{array}$ \\
\hline
\end{tabular}

negara-negara yang berdaulat, yang menjadi bagian dari sistem negara-bangsa dewasa ini, akan tetap mendominasi pembentukan rejim lingkungan internasional walaupun dipandang kurang sensitif terhadap dinamika kerusakan lingkungan yang terjadi. Keohane dan Nye menyatakan dalam bukunya Power and Interdependence bahwa "...teori-teori realis merupakan basis dari model struktural pembentukan rejim internasional... dan model struktural menjadi upaya untuk meningkatkan kemampuan analisa realis dan neo-realis dalam menerangkan berbagai fenomena perubahan rejim internasional" (Keohane dan Nye, 1977:42-6).

Paradigma kedua, yaitu pemikiran ekologis, mengklaim bahwa kekuasaan terlalu terkonsentrasi di tangan negara-bangsa dan bahwa keadaan tersebut mendorong negara-negara untuk berpikiran sempit sehingga menghalangi upaya-upaya perlindungan lingkungan global yang memiliki kecenderungan membutuhkan langkah-langkah kerjasama dan inisiatif- inisiatif yang berwawasan luas ke masa depan. Oleh karena itu, pemikiran ekologis mengusulkan adanya keterlibatan bagian-bagian internal negara sekaligus mendesentralisasikan berbagai mekanisme yang mengatur dan memonitor kegiatan-kegiatan yang mempengaruhi lingkungan hidup. Sangat menarik untuk mengetahui bahwa kedua pemikiran (atau bisa juga disebut "paradigma") mengakui adanya peran negara dalam kerusakan lingkungan yang terjadi dewasa ini dan keduanya berupaya untuk mencari jalan keluar dalam rangka perlindungan terhadap lingkungan.

Analisa terhadap upaya-upaya konseptual dua pemikiran diatas dilakukan dengan tujuan untuk menunjukkan bahwa sementara pembentukan rejim dianggap sebagai langkah radikal dan dapat memperluas pandangan dalam kerangka politik internasional, namun secara implisit upaya tersebut juga membatasi pemikiran tentang usaha-usaha perlindungan terhadap lingkungan internasional yang sedang berkembang saat ini sehingga secara fundamen- 
tal tidak benar-benar melepaskan diri dari orientasi konvensional yang state-sentris. Dalam kerangka rejim lingkungan internasional, perspektif realis dan ekologis sama-sama memikirkan tentang pemindahan kekuasaan dan reorganisasi terhadap skala kehidupan politik. Dengan demikian keduanya dianggap dapat mewakili formulasi yang inovatif dan ekspansif. Namun pada saat yang sama keduanya memahami isu-isu lingkungan hidup hanya sebagai masalah desain institusional dan masalah manajemen saja sehingga membatasi fokus perhatian mereka pada struktur rejim internasional dimana negara-negara terlibat di dalamnya. Jadi, kedua aliran pemikiran itu menempatkan sumber kerusakan lingkungan hidup dalam struktur interaksi antar negara dan melihat harapan bagi perlindungan terhadap lingkungan dalam bentuk sistem kekuasaan yang berbeda. Unit analisa utama dalam kedua perspektif adalah peran negara dalam (pembentukan) rejim lingkungan internasional dan bahwa keduanya memandang perlu diadakan reorientasi terhadapnya. Dengan demikian, walaupun dapat dianggap inovatif, analisa menguatkan orientasi yang menempatkan negara sebagai fokus dari kegiatan politik.

Keseluruhan proses refleksi teoritis yang dilakukan disini dapat diarahkan dengan pertanyaan:Sejauh mana relevansi dan keterbatasan perspektif realis dapat mengakomodasikan pemikiran-pemikiran ekologis sekaligus menawarkan kerangka kebijakan lingkungan hidup global?

Dominasi perspektif atau pemikiran realis dengan tiga asumsinya yang sangat percaya bahwa:(1) negara adalah pemain utama di panggung politik dunia; (2) negara bertindak rasional atas dasar kepentingannya sendiri, dan (3) politik adalah upaya untuk memperoleh kekuasaan dalam hubungan internasional semakin memperkuat posisi negara dan menjadi tema sentral dalam tradisi ilmiah politik internasional dan studi hubungan internasional. Apapun tingkat analisa (level of analysis) yang dipilih dalam suatu penelitian:tingkat sistem, tingkat negara ataupun tingkat individual, maka keputusan (policy) negara sebagai individu-lah yang akan sangat menentukan (Rourke, 1986:45). Realisme para pembuat keputusan di tingkat negara menjadikan berbagai hal lain seperti tingkat perekonomian dan kesejahteraan di dalam negeri hanya menjadi bahan pertimbangan untuk membuat keputusan luar negerinya (Gilpin, 1981:10). Konsekwensinya adalah, relevansi kerangka pemikiran kaum realis untuk menganalisa isu-isu baru, termasuk lingkungan hidup, dalam politik global lalu dipertanyakan.

Status negara, dalam keadaan dimana saling ketergantungan di dunia cenderung makin kuat, lalu seringkali mengundang perdebatan. Pada tahun 1970 an, ketika jaringan hubungan perekonomian dunia berkembang semakin rumit, muncul spekulasi bahwa kedaulatan negara akan segera dianggap ketinggalan jaman dengan berkembangnya perusahaan-perusahaan multinasional. Selain itu, ancaman perang nuklir juga membuat beberapa pihak sempat berpikir tentang pembentukan pemerintahan dunia yang akan menggantikan sistem negara-bangsa (Lipschutz dan Conca, 1993:94). Namun demikian, negara terus bertahan dan terus menguatkan saling ketergantungannya melalui berbagai bentuk kerjasama dalam rejim internasional. Fenomena ini kemudian dikenal sebagai "kerjasama dalam anarki" yang mendominasi berbagai literatur hubungan internasional pada mulai dekade 1980-an.

Pertanyaan yang kemudian muncul adalah:mengapa beberapa negara mendukung kebijakan lingkungan internasional sementara yang lain menentang, atau mempunyai sikap dan pendapat berbeda tentang usaha-usaha pelestarian lingkungan hidup. Mengingat bahwa masalah lingkungan hidup terkait erat dengan masalah ekonomi, dan bahkan diakui bahwa salah satu ciri dari politik lingkungan internasional adalah keterkaitannya yang erat dengan struktur perekonomian global, maka jawabannya terletak pada persepsi yang dimiliki oleh tiap-tiap negara mengenai isu lingkungan hidup global serta pada kondisi perekonomiannya.

Secara realistis beberapa negara memandang bahwa kebijakan lingkungan global akan menguntungkan mereka sementara yang lain merasa secara ekonomis akan dirugikan. Selain itu juga diketahui bahwa 
masalah-masalah lingkungan global tidak akan dapat ditanggulangi oleh kekuatan pasar dalam sistem politik-ekonomi dunia yang ada sekarang sehingga negara mau tidak mau harus terlibat dalam berbagai kegiatan yang melibatkan intervensi domestik sekaligus kerjasama internasional seperti yang belum pernah terjadi sebelumnya (Lipschutz dan Conca, 1993:95). Dalam hal ini hanya negara, yang memiliki sumbersumber keuangan dan sumber daya manusia, yang dianggap paling mampu untuk melaksanakan proyekproyek besar dibidang teknis dan ilmiah bagi pengawasan dan pemeliharaan lingkungan global. Negara juga merupakan satu-satunya struktur, yang berdiri diatas persimpangan antara politik domestik dan politik internasional, yang memiliki cukup otoritas, legitimasi politik, dan kontrol atas wilayah teritorial, sehingga dapat mempengaruhi berbagai penyebab kerusakan lingkungan. Oleh sebab itu, isuisu ekologi dianggap dapat meningkatkan kekuatan dan legitimasi negara dengan cara yang berbeda (Lipschutz dan Conca, ibid.). Sikap realisme terhadap alam adalah menganggapnya sebagai suatu wilayah, aset negara atau sebuah bentuk kekayaan. Dengan demikian alam memiliki status sebatas sumber daya yang keberadaannya tidak berarti tanpa campur tangan manusia. Alam dianggap tidak memiliki kehidupan sehingga secara moral hanya membutuhkan manajemen yang dijalankan dengan bijaksana. Karena alam dianggap tidak memiliki "jiwa" maka realis beranggapan bahwa manusia bebas untuk menggunakan dan memanipulasi alam demi kepentingannya sendiri. Perspektif realis disini kembali menunjukkan kekuatannya karena apapun kebijakan yang dihasilkan oleh rejim lingkungan internasional, adalah kepentingan negara, yang sangat erat kaitannya dengan kepentingan ekonomi, yang akan diutamakan.

Kenneth Waltz menyatakan bahwa dari tiga elemen penting dalam struktur internasional, dua diantaranya dianggap bersifat konstan yaitu (1) sistem internasional lebih bersifat anarkis daripada hirarkis; dan (2) dalam sistem internasional terdapat interaksi antar unit yang memiliki fungsi serupa. Elemen yang ketiga bersifat variabel yaitu distribusi power diantara negara-negara yang dapat berbeda antara satu sistem dengan sistem lainnya, dan antara satu periode waktu tertentu dengan periode lainnya. Waltz, dengan pendekatan neorealis-nya, menyatakan bahwa:(1) Struktur ditentukan oleh aktor yang paling kuat; (2) Struktur menentukan keluaran yang dihasilkan dalam tingkat sistem, berupa dorongan untuk melakukan, atau tidak melakukan, tindakan tertentu; atau dalam mengurangi kemampuan satu negara karena adanya kekuatan negara lainnya; dan (3) Hubungan antara struktur dalam sistem internasional dengan tindakan para aktor dijelaskan dengan asumsi rasionalitas, dimana negara menentukan kepentingan dan strategi yang diambilnya berdasar pada perhitungan tentang posisi mereka di dalam sistem tersebut (Waltz, 1979:93).

Dengan landasan pemikiran diatas dapat dibuat asumsi sebagai berikut:

a. Relevansi pemikiran realis terhadap isu-isu lingkungan hidup internasional akan tergantung kepada kesamaan asumsi-asumsi dasar pemikiran realis dengan asumsi-asumsi yang timbul dalam upaya memahami persoalan ekologis

b. Dalam pemikiran ekologis terdapat sejumlah asumsi yang tidak dipahami oleh perspektif realis sehingga berakibat pada keterbatasannya dalam menawarkan kerangka kerangka kebijakan lingkungan hidup.

\section{KONSEP DASAR PEMIKIRAN REALIS}

Penganut realisme dalam HI ingin memahami dunia ini seperti apa adanya. Walaupun kadangkala yang kita anggap realitas itu tumpang tindih dengan apa yang ingin kita lihat. Adakalanya kenyataan atau fakta itu lalu tidak dapat lagi diperdebatkan ataupun diingkari, sebagai contoh, jumlah penduduk dunia, yang diperkirakan akan melebihi angka 6 milyar pada tahun 2000 (Pirages, 1978:4) atau naik-turunnya tingkat produksi minyak negara-negara anggota OPEC. Contoh lain adalah teknologi luar angkasa Amerika Serikat dan Uni Soviet yang telah sampai pada pembuatan pesawat ulang-alik adalah nyata. Namun demikian, hubungan internasional ternyata tidak hanya mendasarkan diri pada kenyataan yang ada, 
tetapi seringkali lebih kepada persepsi yang dimiliki oleh para aktornya. Para ilmuwan HI menyatakan bahwa yang menjadi penghubung antara persepsi dengan kenyataan politik internasional adalah konsep operational reality (Rourke, 1986:26). Dalam keadaan itu, fakta sebetulnya dapat berubah oleh adanya persepsi (yang kadang salah) dan mendasari perilaku para aktor. Dengan demikian, hubungan dalam arena politik internasional bukanlah sekedar kenyataan obyektif tetapi dapat melibatkan penilaian subyektif yang didasarkan pada berbagai gambaran yang dimiliki oleh seorang aktor mengenai dirinya sendiri dan mengenai aktor lain dalam arena politik internasional. Pada akhirnya, apa yang dianggap penting oleh suatu negara pada satu saat mungkin saja bukanlah hal yang benar-benar penting tetapi hanya sesuatu yang dianggap seharusnya begitu (Dahlan, 1996:200).

Perspektif realis, atau realisme, muncul sebagai reaksi terhadap utopianisme, bersifat normatif dan berorientasi pada produk atau kebijakan praktis (Environmental Politics, 1995:4). Realisme berasumsi bahwa pada pokoknya tidak terdapat keharmonisan kepentingan diantara negara-negara karena diantara mereka ada perbedaan komposisi kapabilitas (power). Perbedaan ini terlihat tidak hanya dibidang militer tetapi juga pada tingkat teknologi, perekonomian, sumber-sumber alam, faktor geografis, bentuk pemerintahan, kepemimpinan politik, ideologi, dan lain-lain (Dahlan, 103-04). Dengan demikian kaum realis beranggapan bahwa prinsip-prinsip moral tidak dapat menjadi acuan tindakan politik karena seorang negarawan yang bertindak secara rasional atas nama kepentingan negara jelas mewakili standar tingkah laku yang berbeda dari standar perilaku individual.

Pandangan kaum realis bahwa negara-bangsa (nation state) adalah unsur terkecil dari sistim politik internasional menimbulkan asumsi bahwa negarabangsa adalah aktor tunggal yang homogen, yang bertindak rasional untuk mengejar tujuan dan kepentingannya sendiri (Mas'oed dan Arfani, 1992:17). Dengan demikian, negara dianggap sebagai pemilik kekuasaan efektif tertinggi, dan dorongandorongan kekuasaan individual dari level lokal direpresentasikan oleh negara di tingkat internasional. Jadi, menurut kaum realis, dalam sistem politik internasional yang bersifat desentralistis perilaku negara yang kompetitif dan agresif, ataupun sebaliknya, dapat diterima dan disahkan. Konsep negara-bangsa lalu memperoleh kekuatan magis seolah ia adalah organ hidup yang mempunyai kepentingan tersendiri (Mas'oed dan Arfani, 1992:18-19).

Penggunaan konsep negara sebagai aktor tunggal ini seringkali menimbulkan masalah karena dapat saja mengacaukan pemahaman kita tentang hubungan internasional. Namun demikian hal tersebut ternyata tidak mengurangi kekuatannya sebagai kesatuan terbesar, yang dalam sistim politik dunia mempunyai hak untuk merundingkan kepentingan-kepentingannya berhadapan dengan negara lain atau aktor lain dalam HI. Pada kenyataannya, negara memang dianggap bukan satu-satunya aktor dalam HI (Mas'oed dan Arfani, 1992:19).

\section{KONSEP DASAR PEMIKIRAN EKOLOGIS}

Walaupun secara umum terdapat kesepakatan mengenai adanya dua kutub yang dominan dalam ekopolitik namun pembagian pemikiran ekologis dalam dua aspek berbeda yaitu "shallow" dan "deep" memiliki masalah yang serius. Kecenderungan untuk secara eksklusif menganggap dikotomi ini sebagai satusatunya cara untuk memetakan teori-teori ekopolitik dapat berakhir pada gambaran tentang ekopolitik yang tidak lengkap. Ekopolitik (sering disebut sebagai green politics atau politik hijau), menurut John Barry, bukan hanya menyangkut nilai-nilai dan dimensi moral dari hubungan antara manusia sebagai makhluk sosial dengan lingkungan alamnya namun juga menyangkut perubahan ekonomi dan politik yang terjadi, dan bahwa diantara keduanya terdapat hubungan (Eckersley, 1992:3). Sementara dalam dikotomi diatas, hanya pemikiran ekologis yang ekosentris dianggap sebagai "deep" sedangkan lainnya dianggap sebagai "shallow". Pada intinya pembagian tersebut merefleksikan adanya ketegangan filosofis antara pandangan yang ekosentris (lingkungan alam sebagai pusat) dengan yang anthroposentris yaitu manusia 
sebagai pusat.

Menggaris bawahi pendapat dua penulis lain, John Barry menyatakan bahwa terdapat keterbatasan dari pembagian seperti diatas dalam menangkap kerumitan dan berbagai variasi yang dihadapi oleh politik lingkungan (Lihat tabel 2). Dikotomi deep dan shallow dalam pemikiran ekologis pada kenyataannya tidak banyak membantu dalam memahami dan menjelaskan hubungan yang ada diantara kedua faktor ekopolitik diatas (Environmental Politics, 1994:369).

Pembagian dua kutub "filasafat politik hijau" dan "politik hijau" ini bukan saja secara normatif lemah (karena menggunakan ekosentrisme sebagai landasan bagi teori-teori ekopolitik), tetapi juga menjadi kurang signifikan. Karena kecenderungannya untuk lebih menekankan pada pemikiran "deep ecology", masalahmasalah pengaturan sosial dan politik kemudian dianggap tidak terlalu penting. Dalam hal ini akan timbul kesulitan mengenai bagaimana caranya "sustainable society” dapat dicapai dan bagaimana nilai dan prinsip-prinsip sosial dalam hubungan antar manusia akan memperoleh perhatian yang cukup mendalam. Masalah terbesar lain dari dikotomi deep dan shallow adalah yang menyatakan bahwa hanya perubahan sosial dan politik yang ekosentris (mendahulukan alam), dan memiliki motivasi ekosentris, saja yang dapat dianggap sebagai "benar-benar" hijau atau bagian dari ekopolitik (Environmental Politics, 1994:370). Eckersley bahkan menyatakan bahwa ketika berbicara mengenai prioritas utama maka pendekatan ekosentris menganggap posisi manusia di alam ini secara logis lebih utama dibandingkan dengan masalah pengaturan sosial dan politik mana yang paling tepat untuk masyarakat manusia (Eckersley, 1992:29).

Dialog mengenai seberapa besar hutang manusia terhadap lingkungan alam dewasa ini seringkali dilakukan tanpa adanya rujukan kepada politik internasional, kepada teori-teori hubungan internasional atau bahkan kepada pengetahuan tentang etika dalam isu lingkungan internasional. Dengan demikian politik praktis seringkali bukanlah bagian dari berbagai pertimbangan dalam pembuatan keputusan (Current History, 2000:361). Lebih jauh lagi, jarang sekali ilmuwan hubungan internasional menghubungkan studi mereka dengan etika ekologis.

Kaum intelektual pada umumnya membagi aspek intelektual dari isu degradasi lingkungan menjadi dua kategori. Kategori pertama mendasarkan diri pada pendekatan manajerial terhadap masalah-masalah lingkungan hidup dan percaya bahwa masalah tersebut dapat diatasi tanpa harus melakukan perubahan mendasar terhadap nilai-nilai dan pola-pola konsumsi serta produksi yang sedang berlaku. Kategori kedua secara umum beranggapan bahwa eksistensi berkelanjutan (sustainable existence) yang bermutu membutuhkan perubahan radikal pada hubungan manusia dan dunia non-manusia, serta perubahan bentuk kehidupan sosial dan politik (Dobson, 1995:1). Kategori kedua inilah yang sering disebut sebagai pemikiran ekologis yang menjadi fokus utama dari ekopolitik di abad-20.

Ada tiga kritik yang sering dilontarkan terhadap pemikiran atau perspektif ekologis. Pertama, kritik terhadap etika antroposentrisme yang mendominasi hubungan manusia dengan alam dewasa ini. Menurut perspektif ekologis dunia non-manusia juga memiliki nilai intrinsik yaitu alam memiliki nilai bukan hanya karena nilai instrumentalnya bagi manusia tetapi karena alam sendiri juga memiliki kualitas intrinsik seperti manusia. Dengan tegas mereka menolak pemikiran adanya garis pemisah, yang secara moral dianggap relevan, antara umat manusia dan dunia nonmanusia, serta menolak pendapat yang menyatakan hanya manusia yang menjadi sumber nilai, dan keberadaan dunia non-manusia tidak lain adalah untuk melayani manusia (Eckersley, 1992:51).

Kritik kedua muncul karena anggapan bahwa konsepsi antroposentris terhadap alam pada perspektif ekologis dimunculkan dengan sengaja dalam sejarah. Pandangan dunia yang sangat antroposentris muncul diantara masa renaissance dan revolusi industri. Saat itu pandangan organik terhadap alam yang menjadi ciri dari masa pra-modernisasi lalu digantikan oleh pandangan mekanistis terhadap modernisasi yang membuat alam tidak lagi memiliki nilai intrinsik. Inti dari kritik yang kedua ini adalah adanya hubungan erat 
Tabel 2. Peta Pemikiran Ekologis

\section{DEEP ECOLOGISTS SHALLOW ECOLOGISTS}

Nilai intrinsik alam yang sangat penting bagi kemanusiaan
Nilai-nilai ekologis - dan hukum alam lain menentukan tingkat moralitas manusia

Biorights - atau adanya hak yang dimiliki oleh species yang terancam punah maupun bagian alam yang unik untuk tidak dirusak
Percaya bahwa eksploitasi sumber alam dan pertumbuhan ekonomi dapat berlangsung bersamaan apabila:

a. Dilakukan cukup penyesuaian pada ongkos produksi, pajak, dll

b. Peningkatan kepastian hukum mengenai level minimum dari kualitas lingkungan

c. Pengaturan kompensasi memuaskan bagi pihak yang mengalami pengaruh sosial maupun lingkungan yang merugikan

Menerima tehnik-tehnik penilaian baru serta keputusan tentang pengaturan yang memungkinkan adanya diskusi yang lebih luas serta penggalian kemungkinan adanya konsensus diantara wakil pihak-pihak yang berkepentingan

(Disarikan dari Riordan, 1981:31)

antara modernisasi dan degradasi lingkungan hidup. Masalah-masalah biasa yang terjadi sehari-hari dalam dunia modern dituduh sebagai sumber kerusakan lingkungan dan lebih banyak menimbulkan kerugian daripada kebaikan, terutama apabila kita mengingat kebutuhan generasi berikutnya (Current History, 2000:361)

Kritik ketiga muncul karena para pemikir ekologis cenderung untuk lebih mendukung kebijakan lingkungan yang radikal dan bukannya yang muncul dari pendekatan "resource management" yang dihasilkan lembaga-lembaga internasional seperti UNCED. Pemikiran atau perspektif ekologis pada umumnya tidak menyetujui pendekatan "top-down" yang menjadi ciri dari institusi internasional (Redclift, 1996:ch.2). Perspektif ini menginginkan tumbuhnya pemahaman yang lebih baik mengenai hubungan manusia dan alam serta mengenai sejarah bagaimana hubungan tersebut telah berkembang kearah yang tidak menguntungkan dan bahkan mengganggu. Pemahaman yang lebih baik diharapkan akan menjadi basis rasa tanggung jawab manusia terhadap akibat dari tindakannya terhadap alam. Diyakini oleh para pemikir ekologis bahwa sebelum terjadi perubahan terhadap pemahaman manusia tentang alam, akan sangat sulit tercipta perjanjian yang efektif mengenai perlindungan lingkungan global.

Pemikiran ekologis juga sangat dipengaruhi oleh dua etika lingkungan lain, yaitu yang biocentric dan ecocentric. Etika biocentric berusaha mencari pemecahan dalam etika antroposentris dalam lingkungan hidup dengan memberikan posisi moral bagi makhluk hidup lain selain manusia. Manusia hanyalah salah satu species diantara penghuni alam ini yang memiliki nilai moral (Callicot, 1989). Sementara itu, etika ecocentric menukik lebih dalam lagi dari yang memiliki nilai moral. Ecocentric menganggap bahwa dalam ekosistem terdapat prinsip memakan dan dimakan sehingga manusia dianggap hanyalah salah satu bagian saja dalam rangkaian rantai makanan yang rumit. Oleh karena itu teori-teori ecocentric menganggap bahwa status atau nilai moral menjadi bagian dari seluruh kesatuan ekologis, dari makhluk hidup sampai dengan seluruh sistem planet kita. Etika ecocentric tidak hanya memperhatikan jenis-jenis binatang atau species tertentu saja tetapi menaruh perhatian pada keseluruhan proses evolusi yang melibatkan seluruh lingkungan organik dan non organik (Current History, 2000:362).

Semua etika dalam pemikiran ekologis menyatakan 
adanya kebutuhan untuk melakukan perubahan dalam praktek politik internasional terutama yang berhubungan dengan pengaturan perekonomian dunia. Meningkatnya pengaruh negatif dari proses perekonomian yang dirasakan melampaui batas-batas negara membuat banyak aktor mempertanyakan kemampuan institusi politik yang ada dalam menanggulanginya. Sebagian besar dari pertanyaan itu kemudian berhasil membawa pemerintahan nasional negara-negara untuk menandatangani berbagai perjanjian internasional. Selain itu, perubahan signifikan juga terjadi dalam jumlah dan jenis aktor yang terlibat (negara dan non-negara), isu-isu yang yang dibicarakan, serta dalam hal norma-norma dan prinsipprinsip yang dicantumkan dalam rejim lingkungan internasional.

Meningkatnya jumlah rejim lingkungan yang terbentuk tidak secara otomatis berarti meningkatnya kekuatan dan efektifitas rejim tersebut dalam memecahkan masalah yang dihadapi. Seperti rejim lain pada umumnya, dalam rejim lingkungan internasional terdapat masalah efektifitas penerapannya karena adanya kecenderungan tidak memiliki mekanisme penegakan hukum formal; kemungkinan tidak diratifikasi; dan kemungkinan rejim akan diimplementasikan juga oleh negara-negara yang tidak terlibat dalam perundingan. Keberhasilan maupun kegagalan pembentukan rejim lingkungan internasional dengan demikian bergantung pada banyak faktor dalam konteks internasional.

\section{REALISME DAN EKOPOLITIK INTERNASIONAL}

Reaksi politis yang dilakukan secara kolektif menghadapi isu lingkungan global dan sub global menjadi kenyataan umum mulai dekade terakhir abad 20. Saat itu negara-negara pada umumnya bertindak sesuai dengan kepentingan nasionalnya, baik karena mereka tidak secara langsung dipengaruhi oleh masalah kerusakan lingkungan yang berdimensi global/ internasional atau karena mereka langsung dipengaruhi oleh kerusakan lingkungan yang disebabkan oleh posisi geografisnya berdekatan dengan sumber kerusakan. Selama ini reaksi negara-negara terhadap masalah lingkungan terutama didasarkan pada kebutuhan mereka untuk menanggulangi terjadinya pengaruh langsung terhadap lingkungannya, dan bukan karena pengaruh yang tidak secara langsung dapat dirasakan.

Untuk masalah pemanasan global misalnya, ketakutan negara-negara di dunia ini kebanyakan didasarkan pada pengetahuan mengenai kemungkinan terbenamnya wilayah-wilayah pantai miliknya serta hilangnya wilayah-wilayah pertanian yang subur yang disebabkan oleh karena meningkatnya permukaan laut akibat memanasnya iklim global. Isu-isu lingkungan hidup kemudian berkembang dengan cepat dalam ukuran besarnya bahaya yang mengancam kehidupan di bumi ini, dan seiring dengan itu politik lingkungan internasional tumbuh dan berkembang untuk dapat menghadapi masalah tersebut. Politik lingkungan internasional, sebagai sebuah kajian ilmu, baru dilahirkan sekitar seperempat abad yang lalu. Kajian itu dimulai dengan memperhatikan masalah-masalah teknis dan bersifat khusus seperti pengaturan tentang sumber daya kelautan dan polusi udara yang melampaui batas wilayah negara (Eckersley, 1992:8).

Sampai dengan sekitar tahun 1980-an, berbagai kajian tersebut hanya memperoleh sedikit saja perhatian dari komunitas ilmuwan hubungan internasional (HI). Pada saat itu, sebelum akhirnya lembaga-lembaga dan rejim lingkungan mulai bermunculan, secara singkat hanya terlihat terjadi satu kali saja muncul gelombang minat yang cukup besar, yaitu ketika diadakan Konperensi PBB mengenai Lingkungan Hidup Manusia (UNCHE atau United Nations Conference on Human Environment) di Stockholm pada tahun 1972 (Thomas:1992:2).

Duapuluh tahun setelah UNCHE, pada tahun 1992 diselenggarakan United Nations Conference on Environment and Development (UNCED) di Brazil. Konperensi yang kemudian lebih dikenal sebagai KTT Bumi di Rio merupakan reaksi terhadap laporan Komisi Brundtland "Our Common Future" yang diterbitkan pada tahun 1987 yang menyebutkan bahwa pembangunan berkelanjutan (sustainable development) harus diprioritaskan untuk membicarakan krisis di bidang lingkungan hidup yang tidak dapat 
dipisahkan dari krisis pembangunan. Dalam KTT tersebut muncul perbedaan yang sangat besar antara negara-negara maju dan negara-negara berkembang tentang seberapa besar penekanan dapat diberikan kepada proses pembangunan yang berlawanan dengan lingkungan. Demikian juga terhadap pertanyaan tentang apakah pembangunan dan kelestarian lingkungan dapat dipisahkan; dan mengenai program apa yang dapat mendukung pembangunan berkelanjutan.

Negara-negara berkembang melihat krisis lingkungan merupakan bagian dari krisispembagunan jangka panjang sementara negara-negara maju melihatnya semata-mata sebagai masalah teknis jangka pendek di bidang lingkungan. Negara-negara berkembang menganggap perlu dilakukan negosiasi dan diskusi mengenai berbagai penyebab krisis lingkungan yang disebabkan oleh sistim ekonomi internasional yang tidak adil. Negara-negara berkembang menuduh bahwa negara-negara maju hanya tertarik pada gejala-gejala kerusakan lingkungan yang langsung mempengaruhinya dan tidak bersedia untuk mengatasi penyebab utama yang akan membutuhkan perubahan gaya hidup dan pola-pola konsumsi negara-negara kaya (Thomas:1992:11).

Negara-negara berkembang, juga sering disebut sebagai negara-negara Selatan, melihat agenda di bidang lingkungan hidup merupakan buatan negara-negara industri maju yang kaya, atau sering juga disebut negara-negara Utara. Agenda lingkungan dianggap negara-negara Selatan sebagai sebuah kemewahan yang tidak dapat mereka jangkau dan juga merupakan hambatan terhadap program-program pembangunan yang sedang mereka kerjakan. Lebih jauh lagi mereka mencurigai maksud negara maju serta mengkhawatirkan munculnya imperialisme dibidang lingkungan. Hal itu antara lain disebabkan oleh karena kebanyakan dari masalah lingkungan yang mendapat perhatian utama dalam agenda lingkungan adalah masalah-masalah yang langsung mempengaruhi negara maju seperti pemanasan global, perlindungan ikan paus dan isu-isu pelestarian hutan. Masalah-masalah khusus yang menjadi perhatian utama negara Selatan seperti tersedianya air bersih dan meluasnya gurun tidak terlalu memperoleh perhatian (New Scientist, 1992:11).

Perbedaan besar juga muncul mengenai kebijakan dan prinsip-prinsip tentang kedaulatan atas sumbersumber alam, pembagian beban, isu-isu kesetaraan, demokratisasi, pendanaan, peran institusi multilateral, transfer teknologi, keanekaragaman hayati dan bio teknologi, penggundulan hutan serta perubahan iklim. Negara-negara berkembang sangat berkepentingan untuk melindungi kedaulatannya yang mereka anggap berpotensi untuk diserang. Mereka menganggap bahwa perhatian terhadap masalah penggundulan hutan tropis merupakan bentuk lain dari imperialisme terutama ketika menyangkut pembicaraan mengenai pembentukan kebutuhan bersama (global commons) yang secara efektif akan menghapus kedaulatan dari wilayah nasional (Thomas, 1992:12). Apabila Eropa menghancurkan wilayah hutannya sejalan dengan proses industrialisasi, maka negara seperti Brazil menganggap bahwa mereka juga berhak untuk melakukan apa saja dengan wilayah hutannya tanpa campur tangan pihak lain. Negara-negara Selatan juga melihat adanya standar ganda dalam agenda lingkungan ketika negara-negara Utara meminta mereka untuk menghentikan penebangan pohon-pohon di hutan yang menjadi penghisap karbon dioksida, sementara pada saat yang sama negara Utara tidak bersedia untuk melakukan usaha yang signifikan dalam mengurangi produksi karbondioksida yang dihasilkan oleh perkembangan berbagai pilihan energi yang lebih efisien. Agenda lingkungan dalam UNCED 1992 menunjukkan bahwa perubahan lingkungan global kembali memunculkan perbedaan antar negara yang menjadi ciri khas dari perdebatan Utara-Selatan dalam tiga dekade terakhir abad 20.

Politik lingkungan internasional (selanjutnya disebut sebagai ekopolitik internasional) melibatkan banyak isu yang kompleks, dimana masing-masing isu memiliki stuktur dan dinamikanya sendiri. Isu-isu yang mengandung ancaman terhadap integritas biosfir iklim, atmosfir, tanah dan lautan dimana kehidupan manusia bergantung - merupakan isu ekopolitik 
Tabel 3. Perbedaan Persepsi tentang isu lingkungan

\begin{tabular}{lll}
\hline ISU & NEGARA MAJU & NEGARA BERKEMBANG \\
Krisis Lingkungan & Merupakan masalah teknis jangka & Merupakan akibat dari program \\
& pendek di bidang lingkungan & pembangunan jangka panjang \\
Penyebab masalah lingkungan & Mis-manajemen program & Sistem ekonomi internasional yang \\
& pembangunan & tidak adil \\
Fokus perhatian utama & Masalah global, a. I. : pemanasan & Masalah lokal, a.l. : tersedianya air \\
& global, pelestarian hutan, dan & bersih, meluasnya gurun \\
& perlindungan ikan paus & \\
\hline
\end{tabular}

* Disarikan dari berbagai literatur yang digunakan dalam penelitian ini

internasional. Ruang lingkup isu-isu ekopolitik internasional biasanya dikategorikan dalam dua dimensi masalah yang dihadapi:(1) lingkup konsekwensi kegiatan ekonomi tertentu terhadap lingkungan hidup; dan (2) lingkup geografis dari negara (dan aktor non-negara) yang terlibat dalam suatu isu. Jika konsekwensinya bersifat global atau melibatkan aktor dari banyak negara maka isu tersebut termasuk isu ekopolitik internasional atau global. Sesuai dengan ruang lingkupnya, maka dalam ekopolitik internasional banyak dilakukan perundingan atau negosiasi multilateral untuk mencapai kesepakatan global yang bertujuan untuk mengurangi resiko di bidang lingkungan.

Kerangka teoritis rejim dalam studi tentang lingkungan internasional menunjukkan adanya beberapa hambatan bagi terciptanya perlindungan lingkungan yang efektif. Peter M. Haas, Robert A. Keohane dan Marc Levy menyebutnya sebagai 3 C, yaitu problems of collective action, lack of national capacity, dan lack of concern for environmental quality (Haas, Keohane dan Levy, 1993:395-98). Masalah tindakan atau aksi kolektif merupakan isu sentral dalam studi yang menggunakan teori-teori rejim karena menyangkut bagaimana cara membuat para aktor yang masing-masing berdaulat dan memiliki kepentingan sendiri-sendiri dapat bertindak bersama demi menghindari hasil yang kurang optimal. Menurut Haas et al., institusi yang dihasilkan dalam rejim memberi sumbangan yang penting karena memberikan tempat untuk melakukan tawar menawar dimana informasi disebarkan secara merata sehingga dapat mengurangi biaya; rejim juga menciptakan proses negosiasi; memonitor perkembangan yang terjadi serta implementasi kebijakan, dan dapat memberikan verifikasi yang akan mengurangi ketidak pastian diantara para partisipan (Haas, Keohane dan Levy:ibid.:401-02).

Tidak memadainya kemampuan negara untuk menghadapi masalah lingkungan banyak dijumpai di negara-negara berkembang. Sebuah negara mungkin benar-benar ingin ikut dalam kerjasama berbingkai rejim lingkungan internasional, namun tidak tersedianya lembaga-lembaga yang efektif di dalam negeri seringkali berarti bahwa administrasi di dalam negeri tidak akan mampu untuk melakukan kewajibankewajiban yang diatur dalam rejim tersebut. Jalan keluar yang dapat ditawarkan rejim bagi masalah tersebut adalah memfasilitasi transfer keahlian manajemen dan teknis, serta bantuan keuangan (Haas, Keohane dan Levy:ibid.:404-08). Mengenai masalah ketiga, yaitu tidak adanya perhatian (lack of concern) terhadap kualitas lingkungan hidup, Haas et al menegaskan kembali pentingnya peran institusi internasional dalam meningkatkan perhatian terhadap masalah lingkungan hidup (Haas, Keohane dan Levy:ibid.:401). Pada kenyataannya, kebanyakan negara seringkali tidak menganggap bahwa isu lingkungan hidup sebagai masalah utama bila dibandingkan dengan isu-isu pembangunan ekonomi dan pertahanan yang dianggap lebih mendesak. Dilain pihak, lembagalembaga internasional juga memiliki banyak kelemahan dalam upayanya meningkatkan perhatian kecuali apabila mendapat bantuan kekuatan lain, yaitu gerakan lingkungan hidup domestik, dalam menciptakan kondisi yang efektif untuk program-programnya. 
Berbagai alasan yang mendorong negara-negara untuk terlibat dalam berbagai perundingan yang menyangkut rejim lingkungan internasional, bahkan hingga meratifikasi hasil perundingan tentu menjadi signifikan untuk diteliti sehubungan dengan peran perspektif para aktor yang terlibat di dalamnya. Namun sekali lagi, dalam hubungan internasional yang didominasi oleh persepektif realis, negara adalah pemain yang utama dan kepentingannya paling berpengaruh. Oleh sebab itu tentu menarik untuk menyelidiki apakah pertimbangan-pertimbangan ekopolitik internasional juga mengenal realisme politik (HI), atau dengan kata lain apakah realisme (HI) juga sangat berpengaruh dalam ekopolitik internasional. Selain itu, apakah teori-teori tentang rejim dapat langsung digunakan untuk menganalisa berbagai isu politik lingkungan internasional akan membutuhkan pembuktian yang menjadi perhatian dalam penelitian ini.

\section{KETERBATASAN DAN DOMINASI REALIS:SEBUAH PARADOKS}

Realisme pada umumnya dipahami sebagai sesuatu yang amoral. Dalam hal ini negara-negara akan melakukan semua tindakan yang diperlukan untuk menjamin keamanan dan keberadaannya. Masalah survival, atau kelangsungan hidup, berkesan memberi legitimasi bagi pelanggaran terhadap perjanjianperjanjian, penyangkalan, penipuan dan berbagai tindak kekerasan. Siapa yang tidak mampu melakukannya akan lenyap sementara yang paling ahli memainkannya akan mendominasi yang lain (Current History, 2000:363). Moralitas, ketika digunakan, seringkali merupakan selubung dari kepentingan nasional yang ingin dikedepankan. Berikut ini akan dibahas tiga asumsi dasar yang sangat berpengaruh dalam perspektif realis, dan neo-realis, terutama dalam hubungannya dengan isu-isu lingkungan hidup yaitu yang berhubungan dengan posisi negara, posisi pendekatan keamanan serta struktur perekonomian kapitalis yang dianggap sebagai bukti paling tepat bagi kemenangan realis.

Inti pandangan realis yang mengakui bahwa secara alamiah manusia akan membentuk kelompokkelompok yang mengalami berbagai konflik kepentingan karena makin langkanya sumber daya yang ada menjadikan upaya untuk mempertahankan kebebasan dan otonomi kelompok merupakan kepentingan utama karena pada dua hal tersebut bersandar kemampuan para anggota kelompok untuk menjalankan kehidupannya di dalam batas lingkungan negara. Secara implisit, pandangan tersebut menjadi prinsip moral yang utama bagi kaum realis dalam memandang pentingnya kekuasaan negara.

Realis berasumsi bahwa sistem negara, atau politik kekuasaan lain yang melibatkan berbagai kelompok, akan menjadi ciri dalam hubungan antar manusia selama umat manusia mendiami bumi ini. Dalam kerangka pengaturan institusional yang permanen tersebut, sangat sulit bagi etika atau pemikiran lingkungan (dan yang lain) untuk dapat menanamkan pengaruhnya. Pada kenyataannya semua tindakan negara harus memperhitungkan keuntungan tambahan (relative gains) yang akan diperolehnya. Perjuangan bagi kelangsungan hidup dan posisi dominan merupakan pertarungan yang tiada akhir dimana keuntungan kecil yang diperoleh hari ini mungkin akan memiliki konsekwensi yang menentukan keesokan harinya (Current History, 2000:364).

Bagi ekopolitik, penekanan pada pentingnya masalah pertahanan-keamanan memiliki implikasi yang paling penting. Penting sekali bagi militer bahwa negara mengembangkan dan menggunakan teknologi militer paling mutakhir yang tersedia. Bagaimana akibat dari dipilihnya teknologi tertentu terhadap lingkungan hidup sedikit sekali menjadi pertimbangan. Pemilihan terhadap persenjataan nuklir, misalnya. Teknologi persenjataan militer yang paling merusak lingkungan adalah persenjataan nuklir, namun pada saat yang sama persenjataan ini adalah yang paling mampu menunjukkan kekuatan nasional yang dimiliki suatu negara. Dengan demikian, pengaruh dari produksi, penyimpanan, penyebaran dan perlucutan serta akibatnya terhadap lingkungan ketika senjata nuklir dugunakan, menjadi pertimbangan nomor dua.

Dari uraian diatas dapat dilihat bahwa secara 
implisit realisme juga merupakan etika lingkungan. Berlainan dengan ketiga etika lingkungan terdahulu (anthropocentric, biocentric dan ecocentric), realisme memandang lingkungan dan alam hanya memiliki sedikit atau sama sekali tidak memiliki nilai moral. Realisme menunjukkan pilihan tentang bagaimana manusia memandang dan berhubungan dengan alam ini, bukan hanya sekedar pilihan mengenai bagaimana manusia (dan negara) berhubungan antara satu dan yang lain.

Dalam perspektif realis, lembaga-lembaga perekonomian masyarakat harus dapat mendukung kekuatan militer yang paling efektif. Apabila ada suatu negara yang melakukan pilihan untuk menyusun perekonomiannya mengikuti pola pembangunan berkelanjutan jangka panjang, maka mungkin saja negara tersebut segera akan merasa kewalahan ketika menghadapi negara-negara lain yang memacu kekuatan militernya. Negara yang ingin selamat akan berusaha menandingi keberhasilan negara lain dibidang ekonomi dan terus-menerus membuat penemuan-penemuan baru yang akan memberi mereka kemenangan. Kapitalisme yang dijalankan oleh Amerika Serikat dan negara-negara maju lainnya, pada saat ini kelihatannya paling mampu menampung aspirasi militer secara besar-besaran.

Secara implisit realisme mendorong kapitalisme karena dianggap sebagai sistem perekonomian yang paling berhasil dalam meningkatkan kekuatan nasional suatu negara. Kapitalisme telah menempatkan Amerika Serikat pada posisi teratas dalam tatanan internasional. Lebih jauh lagi realisme menunjukkan bahwa karena pembangunan ekonomi akan dapat mendukung kesiapan militer maka pertumbuhan ekonomi otomatis akan mengesampingkan tujuan-tujuan lain termasuk perlindungan terhadap alam. Memelihara kawasan berawa-rawa dianggap tidak dapat memberikan sumbangan kepada keamanan nasional sebanyak memproduksi barang untuk ekspor. Sebagai akibatnya, perspektif realis menempatkan posisi pemasaran (marketing) dalam bentuk yang paling tidak memperhatikan masalah-masalah lingkungan hidup terutama pelestariannya.
Ketika membicarakan produk rejim lingkungan, seperti protokol Montreal misalnya, maka mau tidak mau masalah pengaturan yang mengikat negara-negara dalam instrumen multilateral itu akan membutuhkan law enforcement (penegakkan hukum) dalam proses implementasinya di masing-masing negara. Sementara kepatuhan terhadap protokol diharapkan untuk berlandaskan pada adanya kepercayaan pada saat yang sama, seperti yang yang terjadi dengan berbagai perjanjian hukum internasional yang lain, tidak terdapat international enforcement powers (kekuatan internasional yang dapat memastikan implementasinya). Semua penandatangan protokol diwajibkan untuk melaporkan kemajuan dalam mencapai target kepada UNEP tetapi verifikasi akan sangat sulit dilakukan karena badan-badan pemerintah yang harus mengumpulkan laporan tersebut sangat bergantung kepada kejujuran dan pengetahuan yang dimiliki oleh sektor industri, misalnya. Kiasan yang tepat untuk itu mungkin adalah:"Seperti macan ompong alias Tak bergigi”.

Ekopolitik internasional atau global kemudian didefinisikan sebagai interaksi yang melibatkan aktor negara dan non-negara yang melampaui batas satu wilayah negara bangsa tertentu mengenai pembuatan keputusan berdimensi internasional yang menyangkut masalah sumber daya alam dan pengelolaan lingkungan hidup. Munculnya isu-isu ini dalam kancah politik internasional merefleksikan menguatnya kesadaran mengenai meningkatnya tekanan-tekanan terhadap sumber-sumber alam dan sistem kehidupan yang mendukung kegiatan ekonomi dunia pada abad ke duapuluh.

Dalam banyak hal, ekopolitik internasional memusatkan perhatiannya pada usaha-usaha untuk merundingkan perjanjian multilateral bagi terciptanya kerjasama untuk melindungi sumber daya alam dan lingkungan hidup. Perjanjian-perjanjian tersebut sebagian besar membentuk berbagai rejim lingkungan internasional, yang tingkat efektifitasnya bervariasi dalam mengarahkan tindakan negara-negara dalam menghadapi masalah lingkungan internasional.

Perbedaan kepentingan yang dimiliki negara-negara 
dalam isu lingkungan hidup membuat tercapainya kesepakatan diantara pihak-pihak yang bertanggung jawab terhadap, dan yang langsung terkena dampak, masalah lingkungan internasional menjadi tantangan politik dan diplomatik serius. Salah satu masalah utama dalam ekopolitik global adalah kemampuan dari satu atau beberapa negara untuk menghambat atau melemahkan perjanjian dan bagaimana cara untuk mengatasi hambatan tersebut. Agar rejim lingkungan dapat terbentuk dengan kuat maka negara-negara dengan kekuatan veto dan koalisinya harus diyakinkan agar tidak menolak pembentukan rejim yang sedang diusulkan, atau paling tidak agar mau berkompromi dengan negara-negara yang mendukung pembentukan rejim tersebut.

Dari penelitian yang dilakukan dapat disimpulkan adanya kekuatan lain yang menghambat efektifitas implementasi rejim lingkungan internasional yaitu dominasi paradigma ilmu-ilmu sosial, terutama dengan perspektif realisnya, yang sedang berlaku yang menghalalkan eksploitasi alam tanpa batas demi alasan pembangunan ekonomi. Namun dengan menguatnya pemikiran ekologis dan kegiatan ekopolitik internasional, paradigma tersebut mulai mendapat tekanan terutama dari "paradigma sustainable development" yang diintrodusir oleh gerakan-gerakan lingkungan hidup. Perubahan menyeluruh terhadap paradigma mana yang akan mendominasi tentu akan membutuhkan waktu lama terutama karena paradigma yang sekarang dominan sangat kuat pengaruhnya dalam institusi politik dan juga dalam institusi ekonomi.

Seperti yang terlihat dalam tabel 4 diatas, maka ketika membicarakan peran realisme pada paradigma ilmu sosial yang masih dominan dan relevansi perspektif tersebut dalam menganalisa masalah-masalah lingkungan internasional dewasa ini, dapat dicatat beberapa alasan kelemahan/keterbatasan realisme serta kekuatan/dominasi perspektif realis dalam pembuatan kebijakan lingkungan hidup global. Sebagian dari alasan tersebut secara alamiah terletak pada perbedaan fundamental beberapa konsep kunci diantara pemikiran realis dan pemikiran ekologis. Secara sederhana dapat dikatakan bahwa paradoks realisme terjadi ketika disatu sisi berbagai perbedaan konsep diantara dua pemikiran tersebut membuat realisme tidak relevan untuk menganalisa masalah lingkungan global; namun di sisi lain ketidak efektifan berbagai rejim dan masih adanya penolakan untuk meratifikasi rejim menunjukkan adanya dominasi realisme yang menempatkan kepentingan nasional/negara diatas segalanya. Dengan demikian dapat dikatakan bahwa teori-teori $\mathrm{HI}$, terutama dalam hal ini yang beraliran realis, sebagai suatu disiplin akademis akan selalu berada dalam posisi periferi apabila membicarakan pemikiran ekologis dan harus melakukan reorientasi pendekatan teoritisnya terhadap isu-isu lingkungan hidup. Perbedaan yang ada dalam dua konsep tersebut diatas secara signifikan berdampak pada jenis keputusan yang diambil oleh tiap-tiap negara atas nama kepentingan nasionalnya.

Karena terdapat perbedaan teoritis yang fundamental diantara pemikiran realis dan pemikiran ekologis dalam memandang rejim internasional, maka kemungkinan teori-teori tentang rejim internasional seperti pendekatan struktural, pendekatan utilitarian dan model tawar menawar institusional, untuk melakukan pendekatan yang lebih kritis terhadap isuisu lingkungan hidup jelas tidak ada karena kecenderungan realisnya. Realisme secara implisit memang memuat pandangan moral mengenai lingkungan, namun sayangnya mengambil bentuk yang paling merusak. Tidak diragukan lagi bahwa perspektif realis memuat deskripsi mengenai bagaimana cara kerja sistem internasional sekarang ini.

\section{KESIMPULAN}

Dibawah ini akan akan dipetakan kesimpulan akhir dari penelitian tentang (1) keterbatasan; dan (2) dominasi peran realisme dalam ekopolitik internasional.

\section{KETERBATASAN PERSPEKTIF REALIS}

a. Konsep dasar realis mengenai peran negara sebagai aktor utama dalam hubungan internasional yang mengesampingkan peran struktur sosial-politik domestik tidak mampu menganalisa dan meramalkan output atau hasil-hasil dari sebuah 
Tabel 4. Perbedaan Konsep diantara Pemikiran Realis dan Pemikiran Ekologis

\begin{tabular}{|c|c|c|}
\hline KONSEP & PERSPEKTIF REALIS & PERSPEKTIF EKOLOGIS \\
\hline \multirow[t]{3}{*}{ Metodologi } & $\begin{array}{l}\text { 1. Setiap level analisa dapat berdiri } \\
\text { sendiri }\end{array}$ & $\begin{array}{l}\text { 1. Setiap level analisa saling } \\
\text { mempengaruhi }\end{array}$ \\
\hline & Sistem bersifat anarkis & 2. Sistem membutuhkan kerjasama \\
\hline & $\begin{array}{l}\text { 3. Unit analisa berbentuk kesatuan } \\
\text { individual }\end{array}$ & 3. Unit analisa adalah rejim \\
\hline \multirow{3}{*}{$\begin{array}{l}\text { Hegemoni dan kekuatan } \\
\text { veto } \\
\text { Implikasi kebijakan }\end{array}$} & $\begin{array}{l}\text { Ditentukan oleh kekuatan ekonomi, politik } \\
\text { dan militernya }\end{array}$ & $\begin{array}{l}\text { Ditentukan oleh tingkat penderitaan } \\
\text { kerusakan lingkungan }\end{array}$ \\
\hline & 1. Langsung/jangka pendek & 1. Tidak langsung/jangka panjang \\
\hline & $\begin{array}{l}\text { 2. "Zero-sum Game" dimana satu } \\
\text { menang yang lain kalah }\end{array}$ & $\begin{array}{l}\text { 2. "Win-win Solution" dimana } \\
\text { semua pihak menikmati } \\
\text { keuntungan }\end{array}$ \\
\hline \multirow[t]{2}{*}{ Orientasi kebijakan } & Pada hasil/output & 1. Pada proses \\
\hline & 2. Anthroposentris & 2. Ecosentris \\
\hline \multirow{3}{*}{$\begin{array}{l}\text { Rasionalitas tentang } \\
\text { lingkungan }\end{array}$} & 1. Implisit & 1. Eksplisit \\
\hline & 2. Cenderung diabaikan & 2. Sangat diperhitungkan \\
\hline & 3. Seringkali Merusak & 3. Memelihara \\
\hline $\begin{array}{l}\text { Hubungan antara sains dan } \\
\text { kebijakan }\end{array}$ & $\begin{array}{l}\text { Bukan keharusan karena sangat } \\
\text { dipengaruhi oleh persepsi }\end{array}$ & $\begin{array}{l}\text { Merupakan keharusan karena data } \\
\text { ilmiah dapat memperkuat fakta yang } \\
\text { ada }\end{array}$ \\
\hline
\end{tabular}

* Disarikan dari berbagai literatur yang digunakan dalam penelitian ini

perundingan mengenai masalah lingkungan internasional.

b. Posisi tawar-menawar dalam pembentukan rejim lingkungan global biasanya merefleksikan keseimbangan situasi sosial-ekonomi dan politik domestik, yang sewaktu-waktu dapat berubah seiring dengan terjadinya perubahan pada keseimbangan domestik tersebut, bergatung pada siapa yang berkuasa dan apa kepentingannya.

c. Peran para elit politik-birokrasi dan ekonomi yang kepentingan parokial dan ideologinya seringkali bertentangan dengan rencana pembentukan rejim lingkungan global tertentu.

d. Peran kelompok ilmuwan yang sangat strategis dalam menyediakan data hasil penelitian yang mutlak dibutuhkan dalam pembuatan keputusan menunjukkan bahwa konsensus ilmiah yang mendapat dukungan luas dapat mempengaruhi penilaian suatu negara mengenai isu lingkungan hidup tertentu. Kadangkala penilaian itu akan keluar dari konsep kepentingan nasional tradisional yang menekankan pada kekuatan ekonomi-politik dan militer.

e. Adanya penilaian yang dilakukan oleh negara-negara terhadap data-data ilmiah yang dihasilkan oleh para ilmuwan menganulir (menghilangkan) konsep pengetahuan yang "bebas nilai" yang secara epistemologis menjadi landasan metodologis yang digunakan oleh kaum realis yang mengklaim dirinya sebagai penganut metodologi positifistik.

f. Pandangan moral yang implisit dalam realisme yaitu bahwa manusia bebas untuk menentukan nasibnya sendiri, untuk mengembangkan dan mendefinisikan ide-ide mengenai kebebasan dan masyarakat yang baik tanpa adanya campur tangan pihak lain - berlawanan dengan pengaturan institusional yang dikuatkan oleh perspektif neorealis. Pada prakteknya, hanya sedikit sekali pilihan yang tersedia terutama ketika negara berusaha mendapatkan keamanan nasional dan menjamin 
kepentingan nasionalnya dengan segala cara.

\section{BUKTI DOMINASI REALISME}

a. Walaupun kenyataan membuktikan bahwa banyak permasalahan lingkungan membutuhkan adanya kerjasama yang melewati batas negara namun sistem internasional yang state-centric dan kompetitif memastikan bahwa sulit bagi kesadaran mengenai lingkungan hidup untuk dapat menuntun pembentukan kebijakan nasional dalam jangka panjang.

b. Kebanyakan isu-isu lingkungan hidup menunjukkan adanya keterlibatan faktor ekonomi yang pada akhirnya akan menentukan bentuk hubungan diantara aktor-aktor yang terlibat dalam isu tersebut.

c. Peran negara yang ditentukan oleh kondisi perekonomiannya, misalnya sebagai negara maju/ industrialis atau sebagai negara berkembang, seringkali dapat menunjukkan siapa yang memiliki potensi kekuatan veto, dan koalisinya, sehingga dapat menjawab pertanyaan mengenai mengapa mereka mem-veto atau tidak mem-veto suatu rejim internasional.

Dengan demikian penelitian ini membuktikan adanya penguatan terhadap orientasi kedaulatan yang menempatkan negara sebagai pusat perhatian dalam bidang politik lingkungan internasional. Paradoks realisme terletak pada kenyataan bahwa sementara banyak gugatan ditujukan terhadap keterbatasan kemampuan realisme dalam merespon persoalan lingkungan global, pada saat yang sama ternyata pemikiran realisme mendominasi berbagai proses pembentukan rejim, sebagai institusi lingkungan internasional, sampai dengan proses implementasinya di masing-masing negara.

\section{REFERENSI}

Callicot, J. Baird, In Defense of the Land Ethic: Essays for Environmental Philosophy, State University of New York Press, Albany, 1989.

Carrol, John E., ed., International Environmental Diplomacy, Cambridge University Press, Cambridge, 1988.

Dahlan, Harwanto, Teori Teori Hubungan Internasional, terjemahan,
UMY, 1996

Dobson, Andrew, Green Political Thought, $2^{\text {nd }}$ ed., Routledge, London, 1995.

Domask, Joseph J., International Environmental Politics and the Brazilian Amazon through a System Approach to International Relations Theory, http://www. Geocities.com/Rainforest/Canopy/ 1316/files/Dissertation.html

Eckersley, Robyn, Environmentalism and Political Theory:Towards an Ecocentric Approach, UCL Press, London, 1992.

Gilpin, Robert, War and Change in World Politics, Cambridge University Press, Cambridge, 1981.

Haas, Peter M., Robert M. Keohane, Marc A. Levy, Institution for the Earth:Sources of Effective International Environmental Protection, MIT Press, Cambridge, 1993.

Keohane, Robert O., Joseph Nye, eds., Power and Interdependence:World Politics in Transition, Little Brown, Boston, 1977.

Lipschutz, Ronnie D., Ken Conca, eds., The State and Social Power in Global Enviromental Politics, Columbia University Press, New York, 1993.

Mas'oed, Mohtar, Ilmu Hubungan Internasional:Disiplin dan Metodologi, LP3ES, Jakarta 1994 , Riza Noer Arfani, eds., Isyu Isyu Global Masa Kini, Pusat Antar Universitas-Studi Sosial, Universitas Gadjah Mada, 1992.

O'Riordan, Timothy, Environmentalism, Pion, London, 1981.

Pirages, Dennis, The New Context for International Relations: Global Ecopolitics, Duxbury Press, California, 1978

Porter, Gareth, Janet Welsh Brown, Global Environmental Politics, Westview Press, Boulder, 1991.

Redclift, Michael, Wasted:Counting the Cost of Global Consumption, Earthscan, London, 1996.

Rourke, John T., International Politics on the World Stage, Brooks/Cole Publishing Company, California, 1986.

Thomas, Caroline, The Environment in International Relations, The Royal Institute of International Affairs, London 1992.

Viotti, Paul R., Mark V. Kauppi, International Relations Theory:Realism, Pluralism, Globalism, MacMilland Publishing Company, New York, 1990.

Waltz, Kenneth N., Theory of International Politics, Addison-Wesley, Reading, 1979.

\section{Terbitan Berkala:}

Current History, Vol. 99, no. 640, November 2000

Environmental Politics, Vol. 3, no. 3, Autumn 1994 , Vol. 4, no. 1, Spring 1995

New Scientist, 21 Maret 1992

\section{Internet Website:}

CITES, http://www.wcmc.org.uk/CITES/ eng/index.html EPA, http://www. Epa.gov/globalwarming/climate/index.html IMO, http://www.uscg.mil/hq/g-m/nmc/imo/imo_what.htm IPCC, http://www.ipcc.ch/about/about.html LINKAGES, http://www.iisd.ca/climate/cop5/negotiations/index.html UNEP, http://www.unep.org/ozone/mont_prt.htm UNEP, http://www.unep.org/ozone/vienna.htm 